УДК 535.2:616-71

Н.В. Безугла, М.О. Безгулий, канд.тех.наук, Ю.В. Чмир

Національний технічний університет України «Київський політехнічний інститут», пр. Перемоги, 37, м. Київ, 03056, Україна.

\title{
Просторова потокова біометрія середовищ еліпсоїдальними рефлекторами
}

У роботі теоретично обгрунтовано та експериментально апробовано можливість використання еліпсоїдальної фотометричної системи для визначення оптичних параметрів біологічних середовищ в рамках чотирьох потокової моделі на відбиття від підкладок при колімованому освітленні. Визначено оптичні параметри печінки свині та м'язової тканини курки в умовах експерименту in vitro на довжині хвилі 632,8 нм. Бібл. 13, рис. 4, табл. 1.

Ключові слова: еліпсоїдальний рефлектор, оптична біометрія потокові моделі.

\section{Вступ}

Використання методів оптичної біомедичної діагностики набуває все більшого поширення 3 огляду на безпечність, простоту реалізації та інформативність застосування оптичного випромінювання у якості зондуючого стимулу низької інтенсивності. Технічні та технологічні засади вимірювання, реалізовані в численних спектроскопічних методах дослідження прозорих середовищ, неприйнятні в застосуванні оптично мутних середовищ, якими в більшості випадків $є$ біологічні тканини, рідини та субстрати. Це обумовлене по-перше, складністю математичного опису процесів поширення світла в мутному середовищі (так в спектроскопії прозорих середовищ використовують три значущі параметри - коефріцієнт поглинання, показник заломлення та товщина шару, у той час як світлорозсіювальний шар характеризується додатково коефіцієнтом розсіювання та кутовим розподілом розсіяного світла), а по-друге, відсутністю простих, надійних і загальноприйнятих експериментальних методик. Теорія переносу випромінювання (ТПВ), що найбільш широко використовується при описі поширення світла в біологічних середовищах, в прикладному застосуванні ґрунтується на вирішенні основного рівняння ТПВ чисельними методами [9], зокрема потоковим моделями. Для отримання прийнятного, стабільного математичного наближення виміряних фотометричних величин та розрахованих оптичних параметрів біологічних середовищ (БС) використовують різноманітні потокові моделі. Двох-потокова модель [11] зіставляє світлові потоки у відповідності до методу дискретних ординат з двома дифузними компонентами, напрямок яких співвісний 3 напрямком падаючого пучка. Трьох-потокова модель включає два дифузних потоки в прямому та зворотному напрямку, а також колімований потік в прямому напрямку. Чотирьох-потокова модель [9] розглядає два колімованих та два дифузних потоки в прямому та зворотному напрямках. Семи-потокова модель [8] складається із шести дифузних потоків у трьох вимірному просторі і колімованого потоку, вона $\epsilon$ найпростішим просторовим представленням розсіяного випромінювання і падаючого лазерного пучка в напівнескінченному середовищі. До переваг потокових моделей відносять простоту і можливість швидкого розрахунку оптичних параметрів біологічного середовища, а відтак i дозу опромінення при терапевтичному застосуванні. Таким чином, 3 огляду на «потоковість» обраної моделі, технічні засоби повинні забезпечити точну реєстрацію відповідних світлових потоків.

Аналітика та переваги використання фоотометричних систем з еліпсоїдальними рефлекторами в практиці оптичної біометрії середовищ розглянуті, наприклад, в [3,4]. Проте не вирішеними залишаються задачі з'ясування можливості, а також доцільності застосування фотометрії дзеркальними еліпсоїдами обертання при вирішенні основного рівняння ТПВ різними чисельними методами для визначення оптичних параметрів БС. Порівняння результатів використання різних математичних методів дозволить розробити критерії точності та достовірності оптичної біомедичної діагностики еліпсоїдальними рефлекторами. Теоретичній та експериментальній апробації запропонованого класу технічних засобів в рамках потокових моделей присвячена дана робота.

\section{Методи та засоби}

Типові методики проведення досліджень для оптичної біомедичної діагностики включають вимірювання світлових потоків у відбитому або у відбитому та пропущеному крізь зразок БС світлі. Оптичні параметри, отримані за першою ме- 
тодикою покладені в основу проведення експерименту в умовах in vivo aбо in situ, у той час як результати реалізації другої методики застосовуються переважно в in vitro дослідженнях.

3 огляду на принципи функціонування запропонованої фротометричної системи [4], а також конструктивні особливості використаних

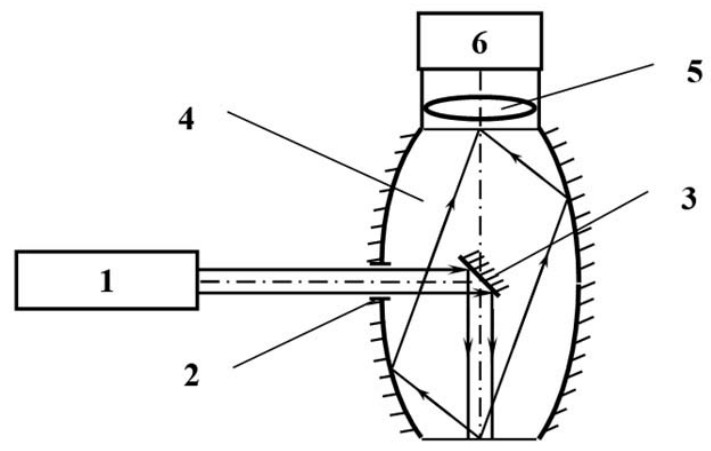

a) еліпсоїдальних рефлекторів при проведенні вимірювань у відбитому світлі (рис. 1), найбільш прийнятною для математичної інтерпретації отриманих світлових величин $є$ чотирьохпотокова модель поширення оптичного випромінювання в БС.

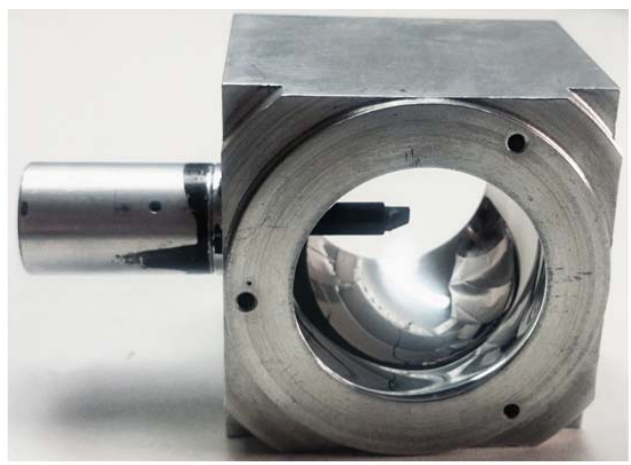

б)

Рис. 1. Еліпсоїдальна фотометрична система: а) структурна схема (1 - джерело монохроматичного випромінювання; 2 - вхідне вікно; 3 - плоске дзеркало; 4 - рефлектор 3 внутрішньою поверхнею еліпсоїда обертання; 5 - узгоджувальна оптична система; 6 - координатний приймач оптичного випромінювання); б) зовнішній вигляд рефлектора

Застосування у якості оптичного стимулу дифузного або колімованого потоку пояснює принципові відмінності використання конкретної потокової моделі. Більшість вимірювальних засобів, що поєднані функціональними та математичними принципами аналізу потокових параметрів, використовують дифузне освітлення. У той же час, запропонована фотометрична система розроблена для роботи з колімованим світлом, тому авторами запропонований процедурний алгоритм визначення оптичних параметрів БС для чотирьох-потокової моделі поширення оптичного випромінювання в рамках методу еліпсоїдальних рефлекторів у відбитому світлі для направленого освітлення (рис. 2).

Розглянемо особливості реалізації запропонованого алгоритму в контексті проведення реального експерименту.

Експериментальна установка складається 3 He-Ne лазеру ЛГН-208А номінальною потужністю 2 мВт на довжині хвилі 632,8 мкм, еліпсоїдального рефлектора 3 фокальним параметром 16,875 мм та ексцентриситетом 0,66, узгоджувальної оптичної системи на базі стереоскопічного мікроскопу МБС-10 та TV-A адаптера, а також монохромної П33 камери DMK-21Au04.AS.

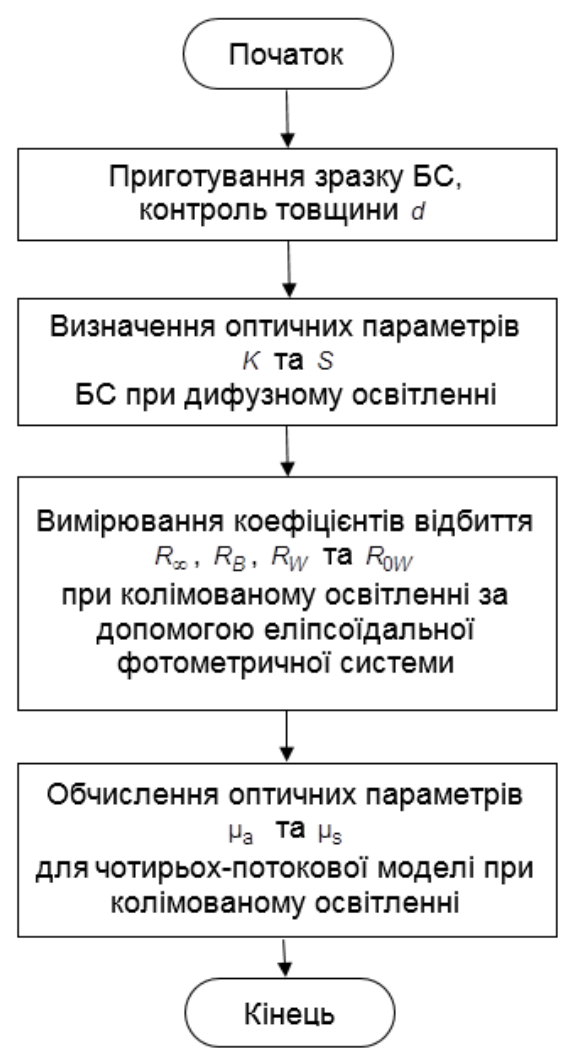

Рис. 2. Блок-схема алгоритму визначення оптичних параметрів БС 
Для дослідження оптичних параметрів БС в якості зразків були використані умовно світлопоглинальне (свиняча печінка особини чоловічого роду, віком 8 місяців, взята через 12 годин після забиття; зразок був заморожений протягом 5 годин при температурі $-18^{\circ} \mathrm{C}$, від якого взято

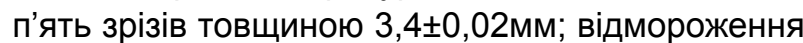
зрізів відбувалось при кімнатній температурі протягом 30 хвилин) та умовно світлорозсіювальне (стегнові м'язи курки-бройлера особини жіночого роду віком 43 дні, взяті через 12 годин після забиття, охолоджені при температурі $5^{0} \mathrm{C}$; було відділено п'ять зразків товщиною

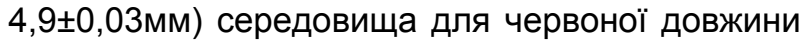
хвилі зондуючого випромінювання. Зразки були отримані у комерційних м'ясників.

Для визначення оптичних параметрів при колімованому освітленні необхідно аби коефіцієнти поглинання $K$ та розсіювання $S$ при дифузному освітленні були розраховані попередньо [7]. Зазначений етап можна реалізувати двома способами. Перший - прямий - полягає в обчисленні коефіцієнтів $K$ та $S$ за результатами вимірювань оптичних потоків в рамках чотирьох-потокової моделі при дифузному освітленні. Але, з огляду на конструктивні особливості еліпсоїдальної фотометричної системи, це здійснити не можливо. Тому, можна скористатись непрямим способом, і розрахувати $K$ та $S$ за відомими оптичними параметрами поглинання $\mu_{\text {adif }}$, розсіювання $\mu_{\text {sdif }}$ та фрактору анізотропії розсіювання $g$ БС при дифузному освітленні, отриманими іншими авторами [5]:

$$
\begin{gathered}
K=2 \mu_{\text {adif }}, \\
S=\frac{3}{4} \mu_{\text {sdif }}(1-g)-\frac{1}{4} \mu_{\text {adif }} .
\end{gathered}
$$

При цьому треба зважити на товщину досліджуваного зразка БС, що вносить суттєвий вклад в значення фактору анізотропії розсіювання $g$ і визначається шляхом додаткових вимірювань, аналогічних гоніофотометричним, описаним в роботі [10]. 3 іншого боку, при біомедичних дослідженнях товщина шару БС для забезпечення максимальної оптичної однорідності складає від декількох сотень мікрометрів до декількох міліметрів, і тому значна частина падаючого випромінювання може пройти крізь зразок. Тому, використання технічного засобу, що забезпечує вимірювання у відбитому світлі, доцільне лише при використанні світлорозсіювальних та світло-поглинальних підкладок з відомими відбиваючими властивостями. Це пояснює застосування математичного апарату чоти- рьох потокової моделі на відбиття від підкладки [7] (рис. 3).

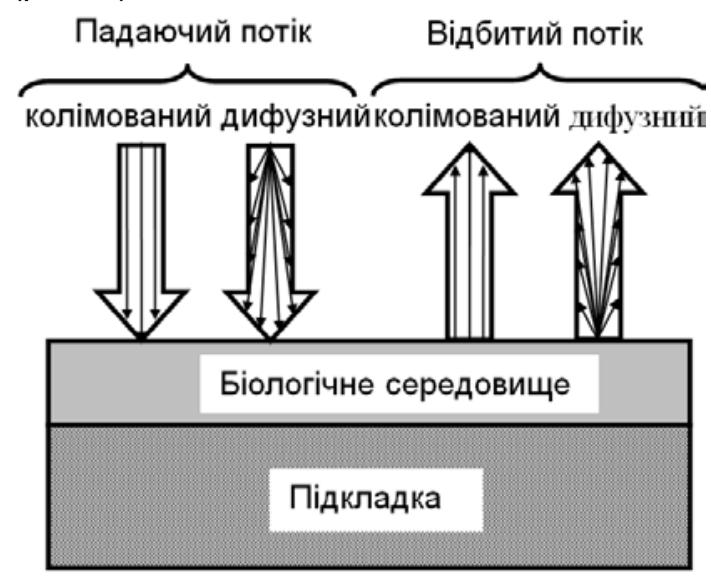

Рис. 3. Зображення чотирьох-потокової моделі на відбиття від підкладки

Окрім інших, значущими величинами, що будуть використані при обчисленні потокових параметрів для направленого освітлення, є:

$R_{\infty}$ - коефіцієнт відбиття шару біологічного середовища «нескінченної товщини» (поняття нескінченної товщини характеризує таку товщину БС, при якій частка пропущеного світла прямує до 0); $R_{B}$ - коефріцієнт відбиття шару БС, що розміщений на чорній (світло поглинальній) підкладці; $R_{W}$ - коефріцієнт відбиття шару БС, що розміщений на білій підкладці з коефіцієнтом відбиття $R_{0 W}$.

У якості білої підкладки було обрано картон 3 нефлуоресцентного білого матеріалу щільністю 225-350 г/м з плоскою матовою поверхнею. Чорна підкладка представляє собою чорний оксамит (100\% поліестр) 3 коефіцієнтом відбиття не більше 1\%. У відповідності до [13] товщина підкладок забезпечувала відсутність помітної частки пропущеного світла, що досягалось багатошаровістю зазначених матеріалів.

Отримані в ході експерименту значення $R_{\infty}$, $R_{B}, R_{W}$ та $R_{0 W}$ у відповідності з методикою, запропонованою в [7], та з урахуванням того, що $R_{0 W \text { dif }}$ - коефріцієнт відбиття білої підкладки при дифузному освітлені, для визначення коефіцієнту пропускання зразка підставляємо в наступний вираз:

$T=\frac{q_{1}\left[R_{W}-R_{B}+q_{2} q_{3}\left(R_{\infty}-R_{W}\right)\right]-q_{3}\left(R_{\infty}-R_{B}\right)}{\tau\left(q_{1} R_{0 W}-q_{3} R_{\infty}\right)}$

де $q_{1}, q_{2}, q_{3}$ та $\tau$ допоміжні величини, що визначаються як: 


$$
\begin{gathered}
\mathrm{T}=\frac{b}{\mathrm{~A}}, \\
q_{1}=a-b, \\
q_{2}=\frac{\sinh (x)}{A}, \\
q_{3}=R_{0 W \text { dif }} .
\end{gathered}
$$

Значення невідомих змінних $a, b, x$ та $A$, що входять до складу (4) - (7), можна отримати 3 наступних співвідношень:

$$
\begin{gathered}
a=1+\frac{K}{S}, b=\sqrt{a^{2}-1}, \\
x=b S d, A=a \sinh (x)+b \cosh (x) .
\end{gathered}
$$

Тоді коефіцієнти розсіювання вперед $s^{+}$i назад $s^{-}$при колімованому освітленні відповідHO:

$$
\begin{aligned}
& S^{+}=p(\mu-a S)+q S, \\
& S^{-}=p S-q(\mu+a S),
\end{aligned}
$$

де $p$ і $q$ допоміжні змінні:

$$
p=\frac{R_{\infty}(1-\tau T)-R_{B}}{q_{1}(1-\tau T)-q_{2}}, q=q_{1} p-\mathrm{R}_{\infty},
$$

а величину $\mu$ можна отримати з закону БугераБера, і з урахуванням (3) та фрренелівських втрат $R_{\Phi}$ :

$$
\mu=-\frac{1}{d} \ln \frac{T}{1-R_{\Phi}} .
$$

Скориставшись виразами (8) - (10), отримуємо коефіцієнт поглинання шару БС для колімованого освітлення:

$$
k^{\prime}=\mu-\left(s^{+}+s^{-}\right) .
$$

Коефіцієнт поглинання (11), а також коефіцієнти розсіювання вперед (8) і назад (9) при колімованому освітленні в рамках чотирьох потокової моделі обчислюються для одержання сталого наближення оптичних параметрів і для отримання оптичних коесріцієнтів $\mu_{\mathrm{a}}, \mu_{\mathrm{s}}$, які згідно 3 [12] визначаються як:

$$
\begin{gathered}
\mu_{\mathrm{a}}=k^{\prime}, \\
\mu_{\mathrm{s}}=s^{+}+s^{-} .
\end{gathered}
$$

\section{Результати і обговорення}

Експериментальна установка дозволяє отримувати просторовий розподіл плями розсіювання, що спостерігається на поверхні біологічного середовища і переноситься за допомогою еліпсоїдального рефрлектора та узгоджувальної оптичної системи на приймальну площину координатного приймача випромінювання. Застосування серійних КМОП або ПЗЗ приймачів, наприклад DCM-35, DCM-500, дозволяє отримувати характеристичний вигляд просторового розподілу світло-розсіювальної плями [2,3,4], проте внаслідок наявності в них блоку автоматичного регулювання підсилення, не прийнятне для здійснення відеофотометрії або ПЗЗфотометрії. У даних дослідженнях був використаний монохромний ПЗ3 приймач DMK21Au04.AS, що дозволяє отримувати «енергетичні» знімки, до котрих можна застосувати принципи фотометрії.

При дослідженнях як з кожного зразка біологічного середовища, так і з кожної використаної підкладки, записувалась серія з 10 знімків у форматі «*.fit», фоотометричні значення з яких були усереднені. На рисунку 4 наведено по одному зі знімків кожної серії для окремого середовища.

Визначивши попередньо коефіцієнт пропускання оптичного тракту еліпсоїдальної фотометричної системи, були розраховані коефіцієнти $R_{\infty}, R_{B}, R_{W}$ для двох зразків біологічного середовища, а також коефіцієнт $R_{0 W}$ для білої підкладки.

На підставі отриманих експериментальних даних та за допомогою математичного апарату (1) - (13) були обчислені коефіцієнти поглинання та розсіювання печінки свині та м'язів курки при колімованому освітленні, що наведені у таблиці 1. 


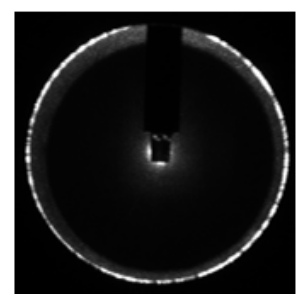

a)

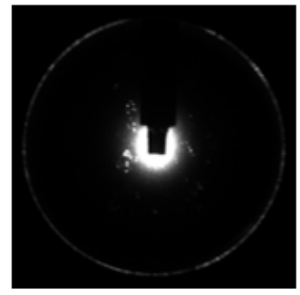

B)

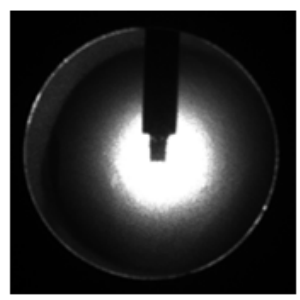

e)

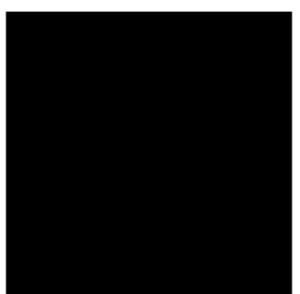

б)

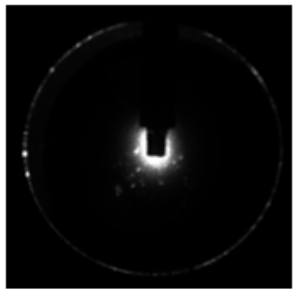

г)

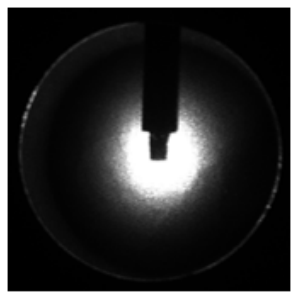

ж)

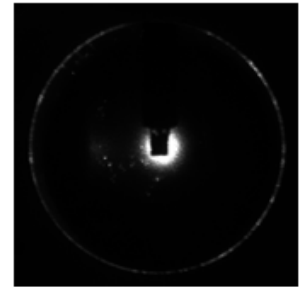

д)

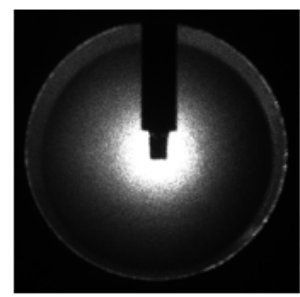

3)

Рис. 4. Фотометричні зображення плями розсіювання на: білій (а) та чорній (б) підкладках; печінці свині $(в, r$, д) та м'язах курки $(e, ж, 3)$ на білій, чорній підкладці та як БС нескінченної товщини, відповідно

Аналіз отриманих результатів показує адекватність використаного математичного апарату чотирьох-потокової моделі в контексті функціонування еліпсоїдальної рефлекторної біометричної системи, що працює у відбитому світлі, для світло поглинаючих середовищ, яким є печінка свині. Для даного середовища відхилення від результатів авторів [1] складає близько 5-11\%, що є прийнятним, з огляду на різні математичні апарати та технічні вимірювальні засоби, що були використанні при обох дослідженнях.

Таблиця 1. Порівняння результатів дослідження

\begin{tabular}{|c|c|c|c|c|c|}
\hline$\lambda, \mathrm{HM}$ & Тканина & Тварина & $\mu_{\mathrm{a}}, \mathrm{CM}-1$ & $\mu_{s}, \mathrm{~cm}-1$ & Метод \\
\hline 632,8 & \multirow{2}{*}{ Печінка } & \multirow{2}{*}{ Свиня } & $6,21 \pm 0,52$ & $68,95 \pm 4,18$ & $\begin{array}{l}\text { 4-х потокова модель для } \\
\text { еліпсоїдальної } \\
\text { фотометричної системи }\end{array}$ \\
\hline 600 & & & 6,56 & 75,96 & $\begin{array}{|lrr|}\text { Інверсний } & \text { метод } & \text { Монте- } \\
\text { Карло [2] } & \text { для } & \text { методу } \\
\text { iнтегруючих сорер } & \end{array}$ \\
\hline 632,8 & \multirow[t]{2}{*}{ М'язи } & \multirow[t]{2}{*}{ Курка } & $0,83 \pm 0,22$ & $7,63 \pm 0,7$ & $\begin{array}{l}\text { 4-х потокова модель для } \\
\text { еліпсоїдальної } \\
\text { фотометричної системи }\end{array}$ \\
\hline 633 & & & 0,17 & 4,1 & $\begin{array}{ll}\text { Наближення } & \text { Помранінг- } \\
\text { Еддінгтона [6] } & \end{array}$ \\
\hline
\end{tabular}

До того ж, така відмінність $є$ допустимою при визначенні оптичних параметрів біологічних тканин, оскільки суттєвими є відмінності і в способі приготування зразків, і в індивідуальних анатомо-фрізіологічних показниках досліджуваних особин. У той же час, менш прийнятними виявились результати досліджень для світло розсіювального середовища, яким $€$ м'язова тканина курки. Так, порівнявши оптичні параметри, отримані в рамках даного дослідження з оптичними параметрами, отриманими в [6], видно, що вони відрізняються в 
середньому на 70-90\%. Це підтверджує обмеженість застосування потокових моделей для дослідження світлорозсіювальних біологічних середовищ та свідчить про необхідність врахування уточнених значень оптичних параметрів для реальної геометрії досліджуваного зразка.

\section{Висновки}

3 огляду на отримані значення величин коефіцієнтів поглинання та розсіювання біологічних середовищ, можна стверджувати про можливість і доцільність застосування методу дзеркальних еліпсоїдів обертання в контексті математичного апарату потокових моделей при колімованому освітленні, що значно спрощує експеримент та скорочує час обчислення оптичних параметрів $\mu_{\mathrm{a}}$ та $\mu_{\mathrm{s}}$. Очевидно, що достовірність отриманих результатів буде більш прийнятною при порівняльній оцінці оптичних параметрів, обчислених в рамках різних математичних моделей опису поширення оптичного випромінювання в біологічних середовищах, за результатами єдиного експерименту на відбиття або на відбиття та пропускання для окремого зразка БС, що $є$ подальшим кроком в дослідженнях 3 використанням еліпсоїдальної рефлекторної фотометричної системи.

\section{Список використаних джерел}

1. Bashkatov A.N., Genina E.A., Tuchin V.V. Tissue Optical Properties / Chapter 5 in: Handbook of Biomedical Optics, David A. Boas (editor). - Taylor \& Francis Group LLC, CRC Press, 2011. - 67-100 pp.

2. Bezuglyi M. A., Bezuglaya N. V. Ellipsoidal reflectors in biomedical diagnostic. // Proc. SPIE 9032. - 2013.

3. Bezuglyi M. A., Pavlovets N.V. Optical biometry of biological tissues by ellipsoidal reflectors. // Proc. OSA-SPIE 8798. - 2013.
4. Bezuglyi M.A., Yarych A.V., Botvinovskii D.V. On the possibility of applying a mirror ellipsoid of revolution to determining optical properties of biological tissues. // Optics and Spectroscopy. - 2012. - Vol. 113. - № 1. - Pp. 101-107.

5. Cheong W-F., Prahl S. A., Welch A. J. A Review of the Optical Properties of Biological Tissues. // IEEE Journal of Quantum Electronics. - 1990. - Vol. 26. - № 12. - Pp. 2166-2185.

6. El-Depsy A., Shawky A.M. Calculation of reflectance and transmittance of coating with optical rough surfaces. // Proc. of the 8th Conference on Nuclear and Particle Physics. - 2011. - Nov.2011. - Pp. 271-280.

7. Hans G.Volz. Industrial Color Testing: Fundamentals and Techniques. - Wiley-VCH. - Federal Republic of Germany, 2002. - 78-96 pp.

8. Hongying Y., Sukang Z., Kejing LI, Ning $P$. Modelling Fabric's Optical Behaviors. // Materials Science Forum. -2008. - Vol. 575-578. Pp.1266-1271.

9. Ishimaru $A$. Wave propagation and scattering in random media. - Acad. Press, New-York. London, 1978. - 572 p.

10. Jacques S. L., Alter C. A., Prahl S. A. Angular Dependence of HeNe Laser Light Scattering by Human Dermis. // Lasers in the Life Sciences. - 1987. - Vol. 1. - № 4. - Pp. 309-334.

11. Kubelka P., Munk F. Ein Beitrag zur Optic der Farbanstriche. // Tech. Phys. - 1931. - Vol. 12. - Pp. 593-601.

12. Van der Zee P. Measurement and Modelling of the Optical Properties of Human Tissue in the Near Infrared. // Thesis submitted for the degree of Doctor of Philosphy of the University of London University of London. - 1992. Pp.113-147.

13. Государственный стандарт республики Беларусь СТБ ISO 22891/ПР.

Поступила в редакцию 04 декабря 2014 г.

\section{УДК 535.2:616-71}

\section{Н.В. Безуглая, М.А. Безгулый, канд.тех.наук, Ю.В. Чмырь}

Национальный технический университет Украины «Киевский политехнический институт», пр. Победы, 37, г. Киев, 03056, Украина.

\section{Пространственная потоковая биометрия сред эллипсоидальными рефлекторами}

В работе теоретически обоснована и экспериментально апробирована возможность использования эллипсоидальной фотометрической системы для определения оптических параметров биологических сред в рамках четырех поточной модели на отражение от подложек при

(с) Безугла Н.В., Безгулий М.О., Чмир Ю.В., 2014 
коллимированном освещении. Определены оптические параметры печени свиньи и мышечной ткани курицы в условиях эксперимента in vitro на длине волны 632, 8 нм. Библ. 13, рис. 4, табл. 1.

Ключевые слова: эллипсоидальный рефлектор, оптическая биометрия, потоковые модели.

UDC 535.2:616-71

\section{N.V. Bezuglaya, M.A. Bezuglyi, Ph.D., Yu.V.Chmyr}

National Technical University of Ukraine "Kiev Polytechnic Institute",

Prospect Peremohy, 37, Kiev, 03056, Ukraine.

\section{Spatial fluxing biometry of environments by ellipsoidal reflectors}

The paper theoretically substantiated and experimentally tested the possibility of using ellipsoidal reflectors system and CCD-photometry for determining the optical parameters of biological environments and tissues. Features of use four-flux model, which describe the light propagation in biological environment in view of collimated and diffuse incident/reflected fluxes, were review. For determine the optical parameters was applied spatial technique with collimated light for reflection from the lightabsorbing, light-scattering substrates and environment of infinite thickness. The optical parameters (absorption and scattering coefficients) of pig liver and chicken muscle tissue in vitro at a wavelength of $632,8 \mathrm{~nm}$ were determined. Ref. 13, fig. 4, table 1.

Keywords: ellipsoidal reflector, optical biometry, flux models.

\section{Reference}

1. Bashkatov A.N., Genina E.A., Tuchin V.V. (2011), "Tissue Optical Properties / Chapter 5 in: Handbook of Biomedical Optics, David A. Boas (editor)”. New-York, London, Taylor \& Francis Group LLC, CRC Press. Pp. 67-100.

2. Bezuglyi M.A., Bezuglaya N.V. (2013), "Ellipsoidal reflectors in biomedical diagnostic". Proc. SPIE 9032.

3. Bezuglyi M. A., Pavlovets N.V. (2013), "Optical biometry of biological tissues by ellipsoidal reflectors". Proc. OSA-SPIE 8798.

4. Bezuglyi M.A., Yarych A.V., Botvinovskii D.V. (2012), "On the possibility of applying a mirror ellipsoid of revolution to determining optical properties of biological tissues". Optics and Spectroscopy. Vol. 113, no. 1, pp. 101-107.

5. Cheong W-F., Prahl S A., Welch A. . (1990), "A Review of the Optical Properties of Biological Tissues". IEEE Journal of Quantum Electronics. Vol. 26, no. 12, pp. 2166-2185.

6. El-Depsy A., Shawky A.M. (2011), "Calculation of reflectance and transmittance of coating with optical rough surfaces". Proc. of the 8th Conference on Nuclear and Particle Physics. Nov. 2011, pp. 271280.

7. Hans G.Volz. (2002), "Industrial Color Testing: Fundamentals and Techniques". Federal Republic of Germany, Wiley-VCH. Pp. 78-96.

8. Hongying Y., Sukang Z., Kejing Ll, Ning P. (2008), "Modelling Fabric's Optical Behaviors". Materials Science Forum. Vol. 575-578, pp.1266-1271.

9. Ishimaru A. (1978), "Wave propagation and scattering in random media". London, Acad. Press, NewYork. P. 572.

10. Jacques S. L., Alter C. A., Prahl S. A. (1987), "Angular Dependence of HeNe Laser Light Scattering by Human Dermis". Lasers in the Life Sciences. Vol. 1, no. 4, pp. 309-334.

11. Kubelka P., Munk F. (1931), "Ein Beitrag zur Optic der Farbanstriche". Tech. Phys. Vol. 12, pp. 593601.

12. Van der Zee P. (1992), "Measurement and Modelling of the Optical Properties of Human Tissue in the Near Infrared". Thesis submitted for the degree of Doctor of Philosphy of the University of London University of London. Pp. 113-147.

13. State Standard of the Republic of Belarus STB ISO 22891/PR. (Rus.) 